\title{
Mont Avic Natural Park - Management Supported by Scientific Research and EMS
}

\author{
Massimo Bocca, Claudio Comoglio, Luca Ganis \& Alessandro Nota
}

\section{Abstract}

The Mont Avic Park protects an area of the south-eastern Aosta Valley (Italy) with particular landscapes and natural features which, until the late 1980s, remained almost unexplored from a scientific point of view. In the course of its twenty years of operation, the park administration has promoted a substantial series of environmental monitoring research projects and campaigns and the protected area is now one of the best-known of the Western Italian Alps.

For the last seven years, the park has also implemented an Environmental Management System which, in 2003, led to its ISO 14001 certification as well as to EMAS registration, thus becoming the first protected area in Italy and in Europe to have received this prestigious recognition by the European Community. The management policy for the protected area, developed through this innovative approach, provides for a continual improvement of the knowledge about the various environmental components through specific scientific research activities, enabling the park administration to create a framework of reference material, which is increasingly comprehensive and constantly updated, and ensuring that adequate management and planning strategies are carried out to protect the biodiversity and promote the territory, with additional positive effects on the local communities and local economy.
Profile

National Park

Mont Avic

Mountain range

Alps

Country

Italy

\section{Historical and territorial context}

Mont Avic Natural Park, the first natural park in the Aosta Valley, was established in October 1989 for the purpose of preserving the natural resources of the upper valley of the Chalamy torrent (Champdepraz municipal district - Aosta Valley region, NW Italy), an area which contains extremely interesting landscapes, and environments hardly touched by human activity. In May 2003, the park was extended to include the "Vallone di Dondena" (Champorcher municipal district), an area of great natural interest thanks to the wealth of flora and high density of typically alpine animal species, such as ibex (Capra ibex) chamois (Rupicapra rupicapra) and marmot (Marmota marmota), as well as outcrops of calcschist, vast meadow areas and numerous alpine lakes. Mont Avic Natural Park currently extends over a total area of 5747 ha.

The main objectives of Mont Avic Natural Park, as set out in the legislation which establishes it, are to regulate and control the use of the area for scientific, cultural, educational and recreational purposes, and to protect, promote and restore the area's landscape and historical, environmental and natural resources.

Since 2002, the park area has been classified as a SIC / ZPS site (IT1202000 - Mont Avic Natural Park) and forms part of the Natura 2000 network.

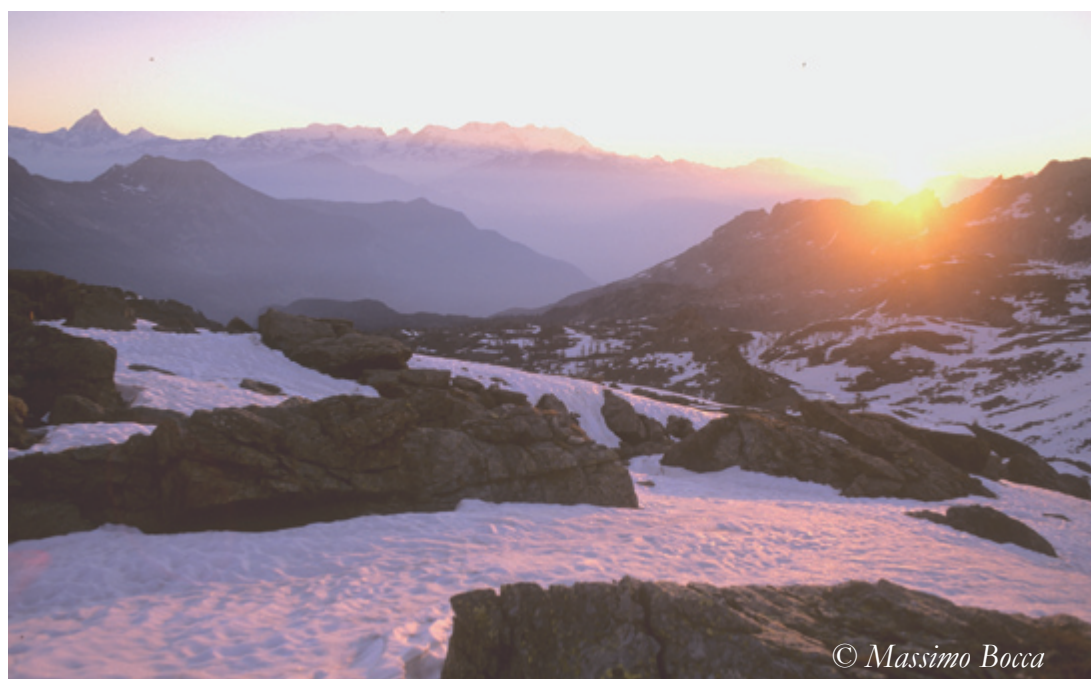

Dawn at Champdepraz; in the background, the Matterhorn and Monte Rosa

\section{Environmental characteristics \& biodiversity}

In morphological terms, the park area is still in an early phase of evolution, with high mountains, deep valleys and very steep slopes. The Champdepraz area forms part of the Piedmont greenstone calcschist area, where outcrops of greenstone alternate with volcanic sedimentary sequences. The surface outcrops of quaternary deposits in the Champdepraz area are frequent and relatively continuous. Morainal deposits appear throughout the valley, mainly from 1300 to $800 \mathrm{~m}$, evidence of large glaciers during the glacial period. 
Champorcher area, Lake Miserin and other small lakes integrate well into the landscape in this "historic" area of the park, where the numerous alpine lakes constitute a unique feature.

The flora and vegetation in the park are strongly influenced by the presence of such a large number of lakes and small wet areas as well as by the abundant outcrops of serpentinite rock which provide shallow infertile soil. In the upper Dondena valley, in Champorcher municipal district, extensive outcrops of calcschist provide the habitat for a rich variety of flora which is quite different from that of the serpentinite rock. The landscape of the protected area is unusual for this region and includes a vast forest of Pinus uncinata. This conifer, rarely found in the Italian Alps, is perfectly suited to the poor soil of the serpentinite rocks and can also grow on the edges of peat bogs. The forest of the Conca di Servaz is classified as a "seed wood" and is looked after by the Aosta Valley Forestry Corps. Forest cultivation activities are carried out within the protected area for the purposes of natural maintenance, using methods permitted for protected woods, but since the park was set up, wood cutting operations have continued on a negligible level.

Another interesting factor is the geographical position of the protected area, which is set between the generally arid mid-Aosta Valley area and the ridges bordering on the fairly humid Piedmont region. In the Val Chalamy, the contrast between the different levels of humidity, from the north-facing slope to the sunny south-facing slope, becomes evident in the gradual transition from beech to Scotch pine (Pinus sylvestris), a tree best suited to the arid conditions.

The interesting flora associated with the humid are-as can be observed not only in the lake basins, but also in a myriad of peaty marshlands and springs throughout the entire protected area. These environments contain boreal species which are now rare and in danger of disappearing in the Alps: the rarest taxa to be found in the peat bogs include Carex limosa, Carex pauciflora and Eriophorum vaginatum. Also notable is the presence in numerous places of the insectivore plant Drosera rotundifolia, as well as a pond with floating masses of sphagnum (including Sphagnum magellanicum, S. squarrosum and $S$. angustifolium).

Rare and localized species of flora in the park include Artemisia chamaemelifolia, Asplenium adulterinum, A. cuneifolium, Cortusa matthioli, Diphasiastrum alpinum, Platanthera chlorantha, Sedum villosum and Stemmacantha rhapontica.

As regards fauna, the notable variety of habitats encourages a large number of insect species, both in the park and in the surrounding areas. There are over 1170 species of lepidoptera, including three species which are new to science (Elachista passerini, E. agelensis, E. baldizzoner); the presence of rare and localized dragonflies and beetles in the humid zones; over 120 species of phytophagous forest beetles, 32 of which were first identified in Aosta Valley.
Among the vertebrates, all of the region's mountain mammals and birds can be found here, including ibex, chamois and marmot (which are especially abundant on the Champorcher side), the mountain hare (Lepus timidus), golden eagle (Aquila chrysaetos), goshawk (Accipiter gentilis), rock ptarmigan (Lagopus muta), black grouse (Tetrao tetrix), rock partridge (Alectoris graeca), eagle owl (Bubo bubo), pigmy owl (Glaucidium passerinum), Tengmalm's owl (Aegolius funereus), black woodpecker (Dryocopus martius), rock thrush (Monticola saxatilis), chough (Pyrrhocorax pyrrhocorax) and the nutcracker (Nucifraga caryocatactes).

The park provides one of only two recognized nesting sites for the European woodcock in the Aosta Valley and has a total of 46 SPEC-listed bird species (Species of European Conservation Concern), codified at European level.

With the exception of the forest species, which benefit from the large expanses of forest, vertebrates do not reach high densities in the park due to the difficult environmental conditions and the limited availability of food.

\section{Infobox}

\section{Mont Avic Natural Park}

\section{Established in 2005}

Main type of ecosystem: alpine valley

Major habitats \& type of land cover:

Forest ( $27 \%$ of total area): natural mountain and sub-alpine broad-leaf and coniferous forests with beech (Fagus sylvatica), pines (Pinus uncinata and P. sylvestris) and larch (Larix decidua)

Pasture and alpine grassland (7\% of total area)

Rocky slopes and debris (64\% of total area), dominated by ophiolites and calcschist

Water bodies: mountain, sub-alpine and alpine streams, lakes and peat bogs ( $2 \%$ of total area)

Location (latitude \& longitude): $45^{\circ} 39^{\prime} \mathrm{N}, 7^{\circ} 34^{\prime} \mathrm{E}$ (central point)

Total size: $5747 \mathrm{ha}$

Altitudinal range (meters above sea level): $1000-3185 \mathrm{~m}$

Management offices: Località Fabbrica, 164, I - 11020 Champdepraz (AO) Email: info@montavic.it

Web: http://www.montavic.it

Unstaffed information point: loc. Fabbrica, near the management offices Information point: Chardonney (Champorcher)

Visitor Centre: Covarey (Champdepraz)

Tel. +39 (0) 125960668

The Visitor Centre includes

an information point where you can obtain detailed information about Mont Avic Park, about the entire "ALPARC" network of Alpine protected areas and about the Italian Federation of Parks and Natural Reserves, and consult nature publications,

a natural history museum which describes the park's rocky areas, wetland areas and forests,

a multi-purpose hall for educational activities, films, conferences and temporary exhibitions. 


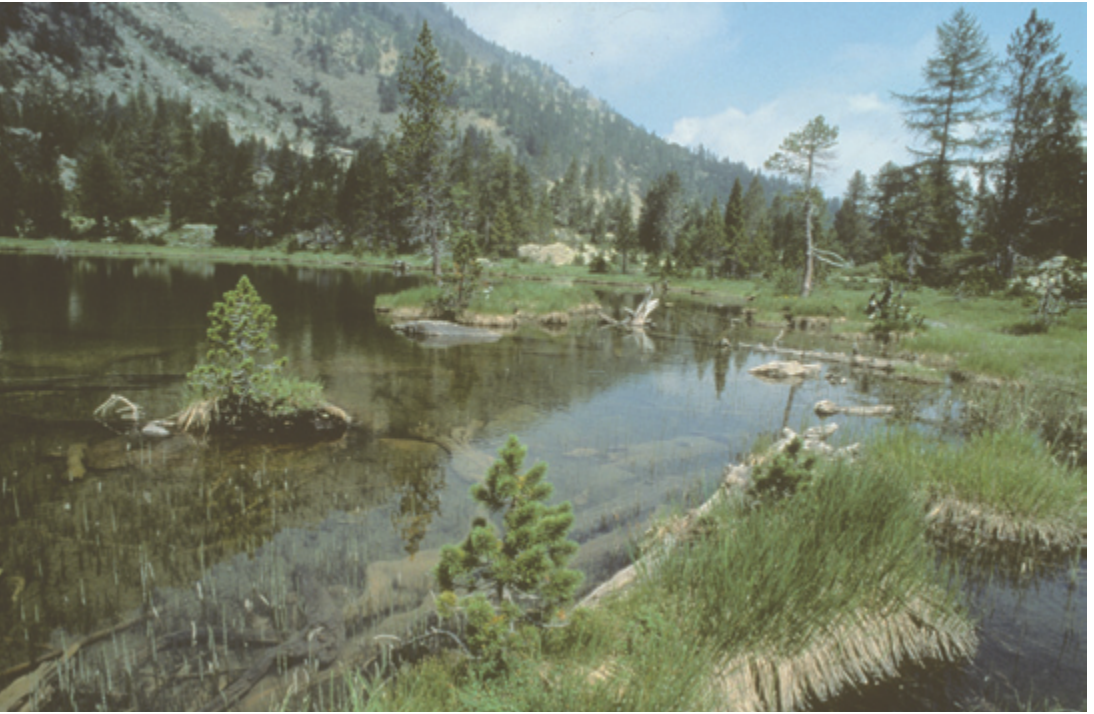

Lake de Pana (C) Maurizio Broglio

In the Val Chalamy, numbers of small mammals are not particularly high and, unusually, in many habitats the numbers of soricidae are higher than those of rodents. Two native species of amphibians and fish, the Rana temporaria and the Salmo trutta fario, populate many wetland areas and streams in the park. In the areas adjacent to the protected area, there are a number of rare thermophile species which are localized within the Alpine region, such as the short-toed eagle (Circaetus gallicus), the blue rock thrush (Monticola solitarius) and the buprestid beetle Coroebus florentinus.

\section{Human presence and visitors centres}

Within the protected area there are numerous mountain pastures, some of which are owned by the regional authority and managed directly by the park administration, others are privately owned. These mountain pastures normally have one or more old buildings, constructed in the local style according to rural traditions, with adjoining grazing land. Their use is limited to the summer period when the animals (generally cattle, sheep and goats) are brought up to graze in the mountains.

The numbers of grazing animals is carefully monitored by the park wardens. In the Champdepraz area, the average number is around 300 a year, most of them cattle, whereas in the Champorcher area, the average is around 600, with equal numbers of cattle and goats or sheep.

The continuation of these pastoral activities is important for the management of the protected area, not only from the social and economic point of view but also from the environmental one, because abandoning mountain and sub-alpine pastures could lead to the meadows being invaded by woodland vegetation and to the eventual disappearance of plant and animal species which are typically found in the open areas, with significant repercussions along the entire food chain. There are also two alpine inns in the park area, one situated near Lac Blanc (Champdepraz) and the other near Lac Miserin (Champorcher), offering accommodation and food for visitors during summer months. In the Champdepraz area there are also various buildings and other remains from past mining activities in the protected area during the $18^{\text {th }}$ and $19^{\text {th }}$ centuries: a paved road with a smooth surface for sledges or carts to facilitate the transport of materials between the Servaz Desot district and Lac Gelé; the ruins of blast furnaces at Servaz Desot and at Perrot; entrances to disused mines and test bores at Colle di Kiva Chevrère, at Lac Gelé and on Mont Ours.

The park's footpath network has been restored and maintained through improvement works to the paths and the draining of surface water, using only local materials (dry stone, wood) and cutting back or taking out vegetation which invades the paths. To channel the flow of tourists, visitors are asked to use only the signposted paths. The influx of visitors is concentrated almost exclusively in the summer months; winter attendance levels are limited and affect mostly the Champorcher side.

\section{Park management}

The Park Administration was specially set up in order to achieve the purposes for which the park was established. It is a non-economic authority, dependent upon the Aosta Valley Regional Authority, with responsibility for operating the park and the power to identify and activate suitable actions to carry out its programmes.

Since 1994, the park also has its own plan, called the Park Territorial Management Plan, which is currently undergoing modification and revision.

The Park Regulation is an integral and more detailed part of the current Territorial Management Plan, with provisions directed toward various activities. The Regulation will be redrafted as soon as the final version of the Territorial Management Plan will be agreed.

\section{Scientific activity, education and environ- mental awareness, environmental monitor- ing}

The park works in conjunction with the Regional Museum of Natural Sciences at Saint Pierre, with various university departments, protected areas and international research groups, including the Grouse Specialist Group, the International Foundation for the Reintroduction of the Grouse into the Alps, and Piedmont Ornithological Study Group.

The park administration is a member of the ALPARC Network of Alpine Protected Areas and of Federparchi, an organization which promotes environmental protection at national and international level and an understanding of the European system of protected areas. It is also one of the founders of the "Ophiolitic Protected Areas Group”, a group which brings to- 
Table 1 - "Cabiers du Mont Avic"

Publications included in the "Cabiers du Mont Avic" series (extracts from Revue Valdôtaine d'Histoire Naturelle)

\begin{tabular}{|c|c|c|c|c|}
\hline & Year & Author(s) & Title & Key words \\
\hline 1 & 1992 & M. Bovio & $\begin{array}{l}\text { Contributo alla conoscenza della flora vascolare della Val Chalamy e } \\
\text { del Parco Naturale del Mont Avic (Valle d'Aosta - Alpi Graie orientali) }\end{array}$ & Vascular flora \\
\hline 2 & 1993 & $\begin{array}{l}\text { E. Brockmann, } \\
\text { F. Hellmann, } \\
\text { P.M. Kristal }\end{array}$ & $\begin{array}{l}\text { I macrolepidotteri del Parco Naturale del Mont Avic e zone limitrofe } \\
\text { (Valle d'Aosta-Val Chalamy Alpi Graie orientali) }\end{array}$ & Lepidoptera, macrolepidopteran fauna \\
\hline 3 & 1994 & $\begin{array}{l}\text { E. Barbero, } \\
\text { C. Palestrini, } \\
\text { M. Zucchelli }\end{array}$ & $\begin{array}{l}\text { Il popolamento di Scarabaeoidea coprofagi (Insecta: Coleptera) del } \\
\text { Parco Naturale del Mont Avic (Valle d'Aosta, Italia) }\end{array}$ & \\
\hline 4 & 1996 & S. De Leo & Contributo allo studio dell'idrologia del Parco del Mont Avic & Hydrology \\
\hline 5 & 1996 & G. Baldizzone & $\begin{array}{l}\text { I microlepidotteri del Parco Naturale del Mont Avic e zone limitrofe } \\
\text { (Valle d'Aosta-Val Chalamy Alpi Graie orientali) }\end{array}$ & Lepidoptera, microlepidopteran fauna \\
\hline 6 & 1996 & $\begin{array}{l}\text { L. Miserere, } \\
\text { G. Buffa, } \\
\text { P. Geissler }\end{array}$ & $\begin{array}{l}\text { Contributo alla conoscenza briologica delle zone umide del Parco } \\
\text { Naturale Regionale de Mont Avic }\end{array}$ & Bryophytes, liverworts, mosses \\
\hline 7 & 1997 & $\begin{array}{l}\text { M. Novelli, } \\
\text { M. Meregalli, } \\
\text { G. della Beffa }\end{array}$ & $\begin{array}{l}\text { Dytiscidae ed Helophoridae (Insecta, Coleoptera) del Parco Naturale } \\
\text { del Mont Avic (Valle d'Aosta, Italia) }\end{array}$ & Hydroadephaga, Helophoridae \\
\hline 8 & 1998 & $\begin{array}{l}\text { R. Piervittori, } \\
\text { D. Isocrono, } \\
\text { L.Usai }\end{array}$ & $\begin{array}{l}\text { I licheni del Parco Naturale del Mont Avic (Champdeprz- Aosta) } \\
\text { Note preliminari sulla flora lichenica rupicola in siti ofiolitici }\end{array}$ & Saxicolous lichen, ophiolitic sites \\
\hline 9 & 1998 & $\begin{array}{l}\text { L. Miserere, } \\
\text { G. Buffa, } \\
\text { F. Montacchini }\end{array}$ & La vegetazione delle zone umide della Val Chalamy (Alpi Graie) & $\begin{array}{l}\text { Subalpine bogs and mires, plant communities, } \\
\text { sphagnum }\end{array}$ \\
\hline 10 & 1998 & $\begin{array}{l}\text { G. Buffa, } \\
\text { L. Miserere, } \\
\text { F. Montacchini }\end{array}$ & $\begin{array}{l}\text { Aspetti della vegetazione d'altitudine del Parco Naturale del Mont } \\
\text { Avic }\end{array}$ & Serpentine, screes, snow beds, mires \\
\hline 11 & 1998 & $\begin{array}{l}\text { G. Badino, } \\
\text { R. Facchini }\end{array}$ & $\begin{array}{l}\text { I macroinvertebarti come indicatori di biodiversità delle zone umide } \\
\text { del Parco Naturale del Mont Avic }\end{array}$ & Macrobenthos, aquatic habitats \\
\hline 12 & 1998 & $\begin{array}{l}\text { E. Barbero, } \\
\text { G. Menetto }\end{array}$ & $\begin{array}{l}\text { Contributo alla conoscenza della coleotterofauna degli ambienti } \\
\text { ofiolitici del Parco Naturale del Mont Avic (Valle d'Aosta, Italia) }\end{array}$ & Coleoptera, alpine fauna, ophiolitic environments \\
\hline 13 & 1998 & G. Curletti & $\begin{array}{l}\text { Prima contribuzione alla conoscenza degli insetti fitofagi del Parco } \\
\text { Naturale del Mont Avic }\end{array}$ & Phytophagous insects \\
\hline 14 & 1999 & $\begin{array}{l}\text { U. Morra di Cella, } \\
\text { B. Fassi }\end{array}$ & $\begin{array}{l}\text { Contributo alla conoscenza dei popolamenti di Pino uncinato del } \\
\text { Parco Naturale del Mont Avic: generalità e metodo di indagine }\end{array}$ & Pinus uncinata, land system \\
\hline 15 & 1999 & F. Peretti & $\begin{array}{l}\text { Ricerche micoecologiche sugli ectosimbionti di Pino uncinato nel } \\
\text { Parco Naturale del Mont Avic }\end{array}$ & Pinus uncinata, fungal ectosymbionts \\
\hline 16 & 1999 & R. sindaco & $\begin{array}{l}\text { I piccoli mammiferi del Parco naturale regionale del Mont Avic e della } \\
\text { Valtournenche (Valle d'Aosta) (Mammalia: Insectivora, Rodentia) }\end{array}$ & Small mammals, insectivores, rodents \\
\hline 17 & 2000 & M. Bocca & $\begin{array}{l}\text { L'avifauna della Val Chalamy e del Parco Naturale del Mont Avic } \\
\text { (Valle d'Aosta, Alpi Graie orientali) }\end{array}$ & Avifauna \\
\hline 18 & 2003 & M. Bovio & $\begin{array}{l}\text { Flora vascolare del Parco naturale del Mont Avic: nota di aggiorna- } \\
\text { mento e presentazione della banca dati informatizzata }\end{array}$ & Vascular flora \\
\hline 19 & 2004 & Autori vari & $\begin{array}{l}\text { Atti convegno: Biodiversità vegetale in "ambienti ofiolitici" (champde- } \\
\text { praz, 2-5 luglio 2003) }\end{array}$ & $\begin{array}{l}\text { Ophiolitic environments, lichens, bryophytes, vas- } \\
\text { cular flora, biodiversity, vegetational typologies }\end{array}$ \\
\hline 20 & 2005 & $\begin{array}{l}\text { G. Pedroni, } \\
\text { F. Francia }\end{array}$ & $\begin{array}{l}\text { La comunità a Coleotteri Attelabidae, Apionidae e Curculionidae del } \\
\text { Parco Naturale del Mont Avic e zone limitrofe (Valle d'Aosta, Italia) } \\
\text { (Insecta, Coleoptera) }\end{array}$ & $\begin{array}{l}\text { Coleoptera, Curculionoidea, biogeography, high } \\
\text { altitude insects }\end{array}$ \\
\hline 20 & 2005 & D. M. Piccolino & $\begin{array}{l}\text { Addenda ai Coleotteri fitofagi del Parco Naturale del Mont Avic e } \\
\text { zone limitrofe }\end{array}$ & Coleoptera, phytophagous insects \\
\hline 21 & 2006 & M. E. D’Amico & $\begin{array}{l}\text { Suoli e ambienti del Parco Naturale del Mont Avic (AO) - 1: piani } \\
\text { subalpino superiore e alpino }\end{array}$ & $\begin{array}{l}\text { Serpentinite soils, gabbro and calcschist soils, } \\
\text { soil-vegetation relationships }\end{array}$ \\
\hline 21 & 2006 & M. E. D’Amico & Suoli e ambienti del Parco Naturale del Mont Avic (AO) - 2: le foreste & \\
\hline 22 & 2006 & $\begin{array}{l}\text { S. Buonuomo, } \\
\text { F. Peretti, } \\
\text { A. Vizzini, } \\
\text { F. Meotto }\end{array}$ & $\begin{array}{l}\text { Sintesi ectomicorrizica in vitro tra Pinus uncinata Miller ed alcuni } \\
\text { Basidiomiceti: risultati e valutazione della crescita }\end{array}$ & In vitro ectomycorrhizal synthesis, Pinus uncinata \\
\hline 23 & $\begin{array}{l}2007- \\
2008\end{array}$ & Autori vari & $\begin{array}{l}\text { Progetto Interreg IIIA "Cogeva-Vahsa": } \\
\text { Sezione A -Studi propedeutici alla stesura del Piano di Gestione Ter- } \\
\text { ritoriale del Parco Naturale Mont Avic } \\
\text { Sezione C - Monitoraggio di habitat nel Parco Naturale Mont Avic e } \\
\text { nei siti Natura } 2000 \text { del Monte Bianco }\end{array}$ & $\begin{array}{l}\text { Biodiversity, Natura } 2000 \text { habitats, lichens, } \\
\text { bryophytes, vascular flora, Araneae, Odonata, } \\
\text { Orthoptera, Lepidoptera, Coleoptera Carabidae, } \\
\text { xylophagous insects, dung beetles communities, } \\
\text { macrobenthos, IBE, atmospheric depositions, } \\
\text { tropospheric ozone, peatland, water chemistry, } \\
\text { alpine streams }\end{array}$ \\
\hline
\end{tabular}


gether parks and reserves containing particular ophiolitic substrates, for scientific purposes as well as for promoting knowledge and awareness.

The researches carried out by Mont Avic Natural Park are published mainly in the "Revue Valdôtaine d'Histoire Naturelle" and articles are edited into extracts for the "Cahiers du Mont Avic" series, which cover topics ranging from hydrology, botany, zoology, forestry sciences and agronomy. The results of other highly specialist research projects have been published in specialist journals in Italy and abroad, or as conference papers.

As regards environmental education, the park organizes educational visits and study training, involving schools and universities in Italy and abroad. The park collaborates with various universities in Italy and abroad in running apprenticeships and thesis studies on ecological topics (study programmes which include field activities lasting for a period of one month or more). Educational activities involving primary and secondary schools have also been carried out in collaboration with the appropriate regional administrative inspectorate.

\section{Infobox}

\section{EMAS}

The objective of ISO 14001 and EMAS is to promote continuous improvement of the environmental performances of the organizations by introducing and implementing a management system for assessing and controlling all interactions between activities, products, services and the environment systematically and with conservation in mind. The scheme requires the organizations to comply with all relevant environmental legislative provisions, to set improvement objectives, to involve their employees and, for EMAS, to provide public information and promote awareness. The correct application of the EMS is verified by an independent third party (certification authority) which issues a certificate of compliance with the relevant standard requirements and, for EMAS, validates the environmental statement. EMAS requires a further approval at institutional level, carried out by the relevant body of each member state. The main phases in the application of the EMS implementation are illustrated below.

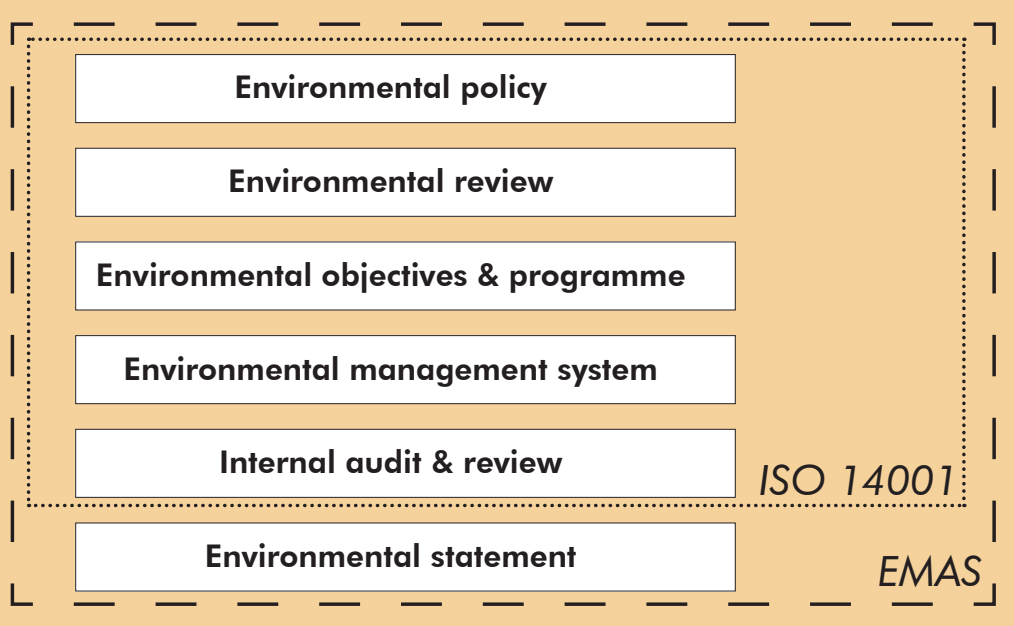

Main implementation phases for ISO 14001 and EMAS
The park offers information services and organizes exhibitions and educational activities. The museum in the Visitor Centre at Covarey covers some of the more special and unusual aspects of the protected area ("the secret park”). For further information see Table 1.

\section{The Environmental Management System}

The Environmental Management System (EMS) has been implemented in line with the environmental policy of Mont Avic Natural Park, and in compliance with ISO 14001 standards and EMAS regulations. The objective of the EMS is to create an optimal management system for environmental aspects in connection with activities carried out on park territory, in order to progressively reduce the environmental impact caused by each operation, thereby ensuring, controlling and demonstrating not only compliance with the current legislation, but also with good environmental practice, consistent with the environmental policy of the organization and its set objectives. The EMS is applied to all activities carried out in the park territory which can interact with the environment and especially with those environmental aspects over which the organization exercises control and which it might be able to influence.

Some of the EMS documents have been adopted as "external instruments" for the new Park Territorial Management Plan. Particularly effective in this respect is the reference to EMS procedures in terms of monitoring, so that it is possible to update the study programmes without having to reapprove the Territorial Management Plan in its entirety, even though it remains officially valid and clear.

The EMS provides for a periodical update of the environmental review report, which identifies and describes environmental aspects in relation to the activities carried out by Mont Avic Natural Park.

It covers the following environmental aspects:

emissions into the air;

discharges into water;

waste production and management;

use and contamination of land;

use of natural resources and raw materials (water, electricity, fuels, etc.);

local issues (noise, odour, hazardous substances, visual appearance, electromagnetic pollution, etc.); transport issues;

risks of environmental accidents and impacts arising as consequences of emergency situations; effects on biodiversity.

For each individual environmental aspect, an adequate qualitative and, where possible, quantitative characterization is carried out, with particular reference to the following elements: specific operations and/or origins of the environmental aspect, any specific legislative provisions and measures already carried out by the organization for monitoring, controlling and mitigating that aspect. 


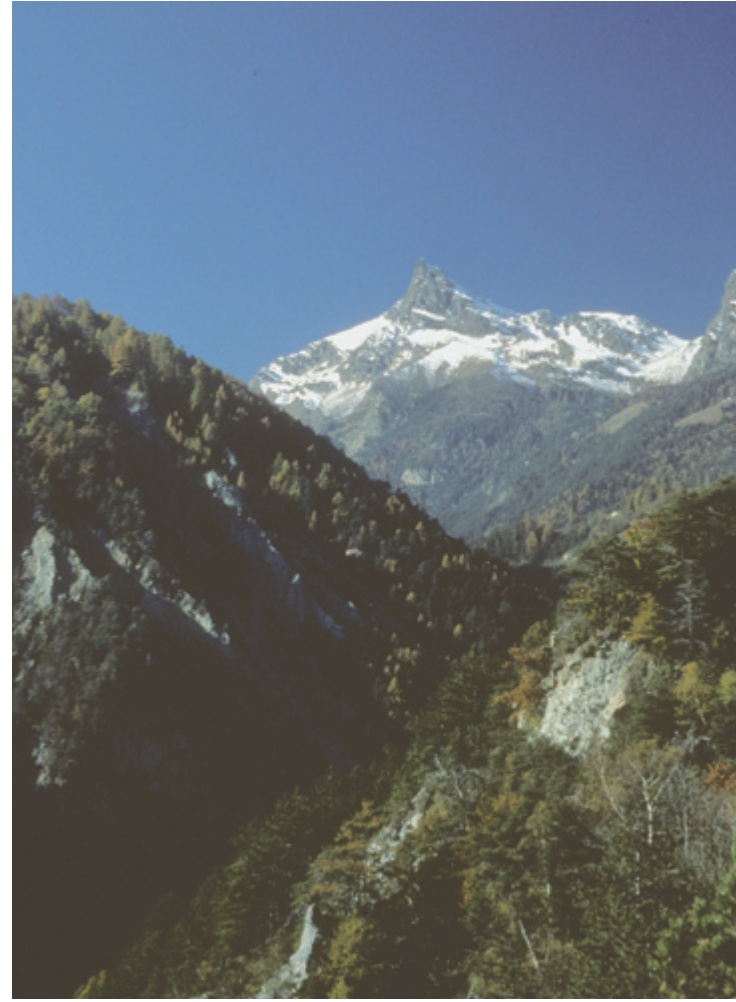

Mont Avic from Champdepraz (C) Massimo Bocca

Once the direct and indirect environmental aspects related to the activities carried out by the natural park have been identified and described, their relative significance is evaluated. An environmental aspect is considered to be significant if it can have a significant impact on the environment.

The aspects which are regarded as significant by Mont Avic Natural Park are discharges into water, the use of water resources and the effects upon biodiversity.

Discharges into rivers and streams are caused by farming, pastoral and forestry activities and by alpine inns, and are very few and of negligible importance. This aspect, however, has been assessed as being significant because the points of discharge from mountain pastures are not subject to legal authorizations. The park intends to include specific provisions in the new Territorial Management Plan on the management of these water discharge points, including the applicability of eco-compatible technologies, in such a way as to limit all possible risk of deterioration for the quality of the waters and water biocoenoses (fish fauna, river vegetation, aquatic macro-invertebrates) as a result of organic discharges from specific as well as general sources. With regard to the use of water resources in the park, there is a large number of small diversion channels from springs and streams for irrigation, domestic, civil, animal feeding and hydroelectric purposes. This aspect too has been assessed as significant, given the high number of diversion channels within the park (a total of 122 diversion channels have been recorded, of which 101 are inside the park): even though they do not use large amounts of water, they do modify, albeit to a limited extent, the water system where they

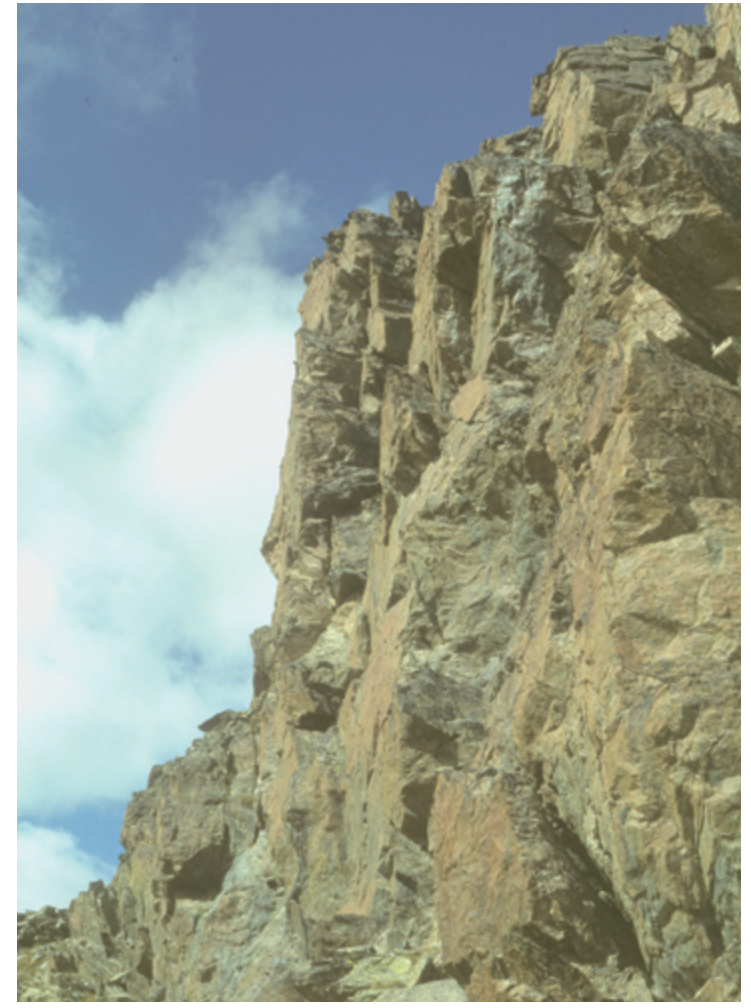

Ophiolite at Mont Tors (C) Massimo Bocca

are situated, with the possibility of causing potential changes to water biocoenoses.

The park administration has created a special GIS archive of all water withdrawals, which are carefully controlled by the park wardens, and now intends to launch a monitoring campaign in order to compare the discharges declared in the authorizations with actual abstraction levels.

The environmental aspect "effects on biodiversity" is considered to be the most significant, if only potentially. The main underlying consideration is the view that inadequate knowledge of the composition of animals, plants and vegetation in the protected area might lead the park administration to make management choices which might compromise vulnerable species about whose presence and / or extent it does not know enough. This potential difficulty has led to the creation of a long-term plan for monitoring activities and scientific research, specifically set up within the EMS environmental programme to gradually fill in the knowledge gaps identified by a periodical review of all databases of the various environmental components in the park.

The activities in the area which have the greatest potential for producing effects upon the biodiversity include the presence of tourists in the area and the use of the land for grazing.

The presence of tourists gives rise to potential difficulties where there is a failure to respect the prohibitions imposed by the Territorial Management Plan, through the possible uncontrolled introduction of domestic animals (with consequent phenomena of disturbing or frightening animal species during delicate phases of 


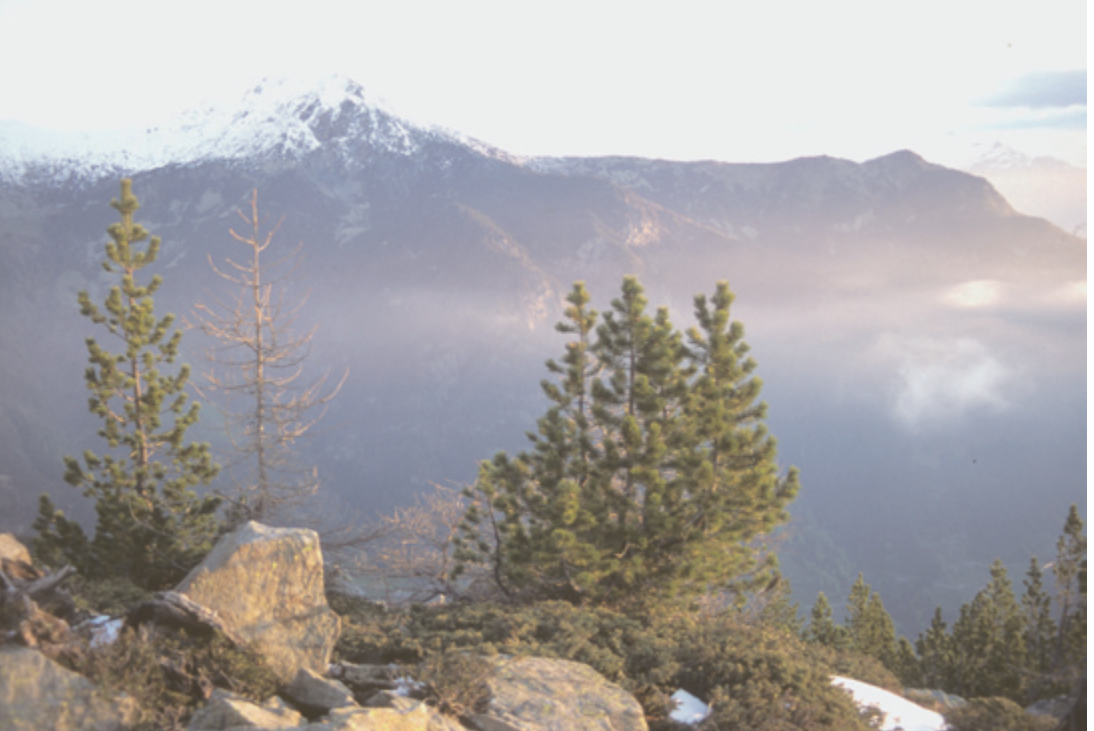

Pinus uncinata (C) Massimo Bocca

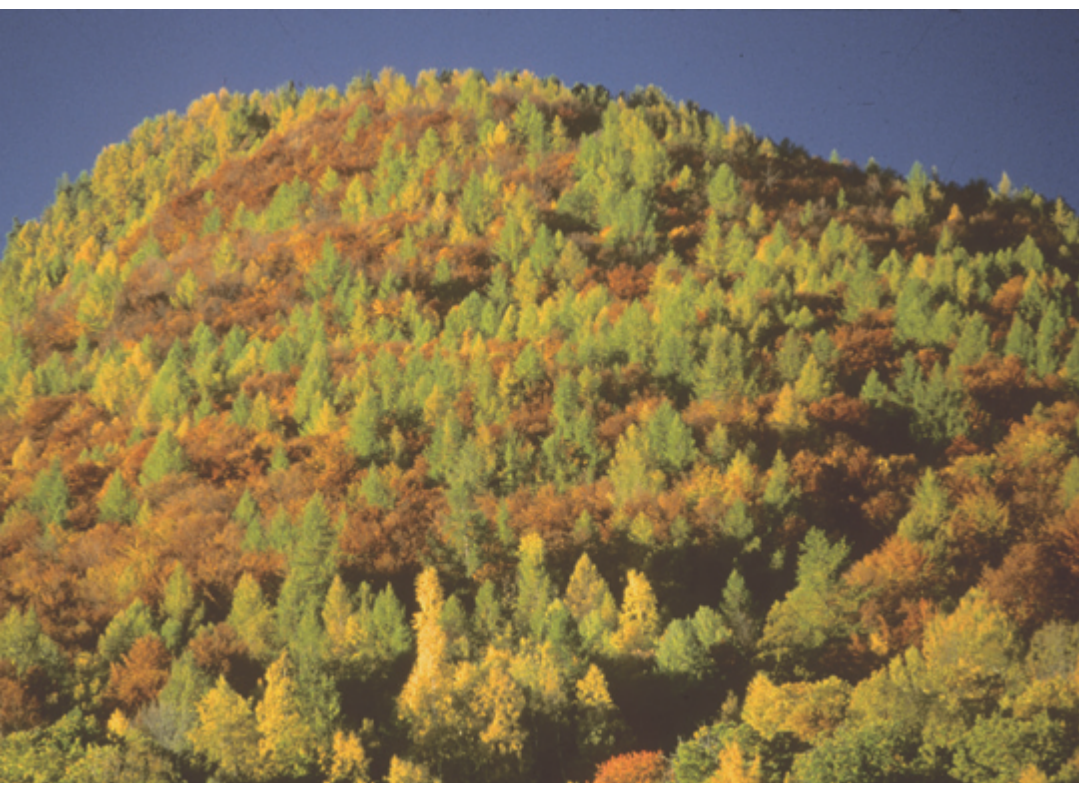

Mixed forest in autumn (C) Stefano Untertbiner

the biological cycle) and especially through the uncontrolled presence of tourists trampling in sensitive areas such as peat bogs and wet areas of major importance (with consequent harm and/or irreparable damage to plant and animal species). The planning decisions of the park administration on channelling the flow of tourists can have a major influence upon this environmental aspect (positioning of information points, routes followed by the network of footpaths, etc.). Grazing practices in the area can have significant effects upon biodiversity where there is a failure to respect the park regulations, through the possible uncontrolled presence of animals and consequent damage to sensitive areas (peat bogs and wet areas) and through an incorrect management of animal manure. At the same time, a possible gradual decline in such activities could cause the pastures to be abandoned in areas at the edges of the mountain and subalpine zone, caus- ing scrub encroachment and leading to the subsequent disappearance of species of plants and animals which are typical for the ecosystem, with long-term repercussions for the entire food chain.

Study and analysis of the environmental aspects provide elements upon which to base the definition of environmental objectives. These objectives constitute the improvement commitments which the park administration voluntarily assumes for continuous improvement in pursuance of its environmental policy. There is a three-year time frame for achieving these improvement objectives as part of the environmental programme, which specifies in detail the actions to be taken to reach each objective, sets out any quantitative indicators for monitoring progress, identifies the person in charge (within the organization), the staff resources (internal and / or external) and funds (budgeted investments, where applicable) and deadlines for completing each individual action.

Of great importance to the Environmental Programme 2006-2009 was the COGEVA-VAHSA project (Coopération, Gestion, Valorisation des Espaces Protégés, Vallée d'Aoste e Haute Savoie), which forms part of the Interreg IIIA ALCOTRA programme. With its support, the park administration succeeded in obtaining the necessary resources to carry out various research activities in its area.

The numerous objectives in the EMS which the park administration was able to plan and achieve (out of a total of 34 objectives in the environmental programme, 30 have been completed, and only 4 remain partially completed and ongoing) include:

Increased knowledge of plants, vegetation and animals in the protected area and optimized data management:

As part of the Environmental Programme 20062009 , botanical studies were carried out on lichen, bryoflora and vascular plants within a campaign for the collection of plant data and studying plants in ophiolitic sites, with the following results:

lichen flora: 126 species recorded, of which 26 were recorded for the first time in the Aosta Valley and 87 recorded for the first time in the park; by adding previously published data, the total of known taxa in the protected area has increased to 185 , some of which are of great interest from a conservation point of view;

bryoflora: 50 taxa identified, of which as many as 23 were newly recorded in the park territory; vascular plants: 71 species identified, which were not previously in the park's flora database, which brings up to 585 the taxa of vascular flora recorded in the protected area.

In December 2006, as part of the Interreg IIIB "Habitalp" project, the Habitats Chart was created; later a reading of MIVIS images was begun, subsequently compared / integrated with the information relating to the environmental and habitat units. 
The periodical acquisition and organization of information on plants, vegetation and animals in the protected area is regulated by a specific EMS procedure. A monitoring manual has been created, containing a list of plant species and types of vegetation to be monitored and the relative survey schedules, and indicating how the collected information is to be stored and georeferenced. The park wardens follow this procedure regularly (at present, 24 priority species have been identified at more than 200 sites, of which 119 relate to species being monitored by the park wardens). The park's plant database, which now contains more than 5600 records, is updated with information from recent studies on vascular plants and there is also a GIS link to mapping for the exact position of the priority species.

The park's animal database contains records with GIS interface as from 31/12/2008, with the following numbers:

- game birds: 4682

raptors: 4570

corvids: 1434 .

Monitoring of species and groups of species, both in woodlands and in shrub vegetation (orthopterous, lepidopterous and coleopterous insects) was carried out in 31 sample areas, with the following results:

orthoptera: 37 species recorded (a considerable number if compared with the total of 65 species known in the Aosta Valley);

- lepidoptera (the study covered only the recently extended area of Champorcher): 71 species of rhopalocera and 148 species of microlepidoptera recorded;

- coleoptera: 25 coprophagous species, belonging to 3 different families.

Increased knowledge of surface waters:

Various monitoring campaigns have been carried out ( 2 hydrometric monitoring stations; 5 thermal monitoring stations; 2 chemical, physical and bacteriological monitoring stations; 5 macrobenthos monitoring stations; 3 fish fauna monitoring stations). The surveys on various types of habitat along the Chalamy and Ayasse torrents have proved to be particularly important in obtaining an initial description of habitats along the Ayasse, for which there had previously been little information, and in gathering additional useful information about the Chalamy for management purposes.

Increased knowledge of atmospheric conditions: Specific monitoring surveys have been carried out in collaboration with the Aosta Valley Environmental Protection Agency on tropospheric ozone (3 monitoring sites, each equipped with 3 samplers) and atmospheric deposits ( 2 monitoring sites, equipped with a total of 11 samplers).

The Environmental Programme 2009-2012 largely continues previous programmes (completing and developing various initiatives already begun in the

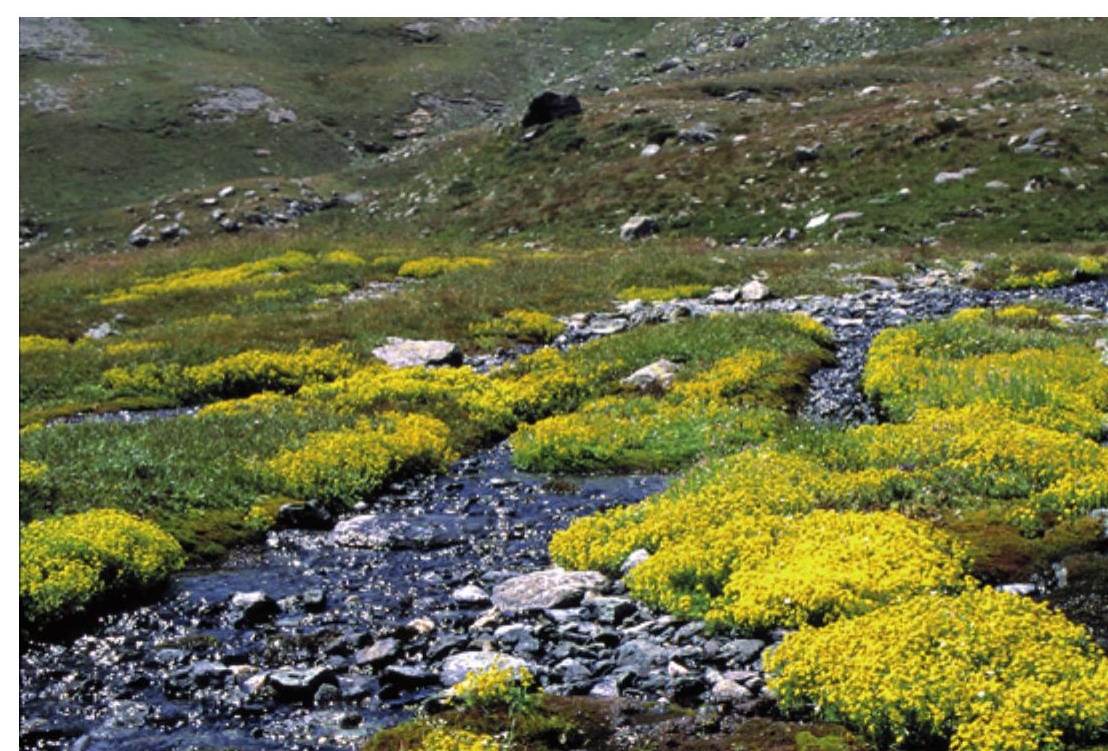

Saxifraga aizoides (C) Massimo Bocca

preceding environmental programme), with a strong emphasis on increasing knowledge of the phenological aspects of plant and animal species in relation to climate changes. These studies form part of the new Phenoalp project (begun in 2009 and set to end in 2011), as part of the "Alcotra 2007-2013" cooperation programme between Italy and France, with the involvement of the Aosta Valley Regional Authority, the Aosta Valley Region Environmental Protection Authority, the Centre de Recherches sur les Ecosystèmes d'Altitude (CREA) and the Parc Naturel Régional du Massif des Bauges (PNMB).

The EMAS Environmental Statement and annual updates provide the main means of communication with the public and with interested individuals. It disseminates reliable environmental information about the park administration's continuing improvements of environmental performance, on how the area is being conserved and promoted, and on its ecosystems and biodiversity.

This document, which can be downloaded from the website at http://www.montavic.it/, provides an annual status report on each environmental project and the main activities carried out in the previous year.

\section{Acknowledgements}

The activities described in this article have been carried out thanks to the commitment and professionalism of the staff of Mont Avic Natural Park, of the Regional Protected Areas Service and of the Aosta Valley Autonomous Region Forestry Corps.

\section{Authors}

\section{Massimo Bocca ${ }^{7}$}

Born 1959. Degree in agronomic sciences and doctoral thesis in entomology. Director of Mont Avic Natural Park since 1991 and member of the CII of 
ALPARC. Author or co-author of more than 40 scientific zoological papers on entomology, herpetology, and particularly ornithology.

info@montavic.it

\section{Claudio Comoglio²}

Born 1972. Degree and doctoral thesis in environmental engineering. Assistant professor at Turin Polytechnic, Engineering Faculty, where he teaches "Applied Ecology" and "Environmental Management Systems". Author or co-author of more than 40 scientific papers on innovative applications of environmental management systems and in the field of eco-hydraulics, environmental flows, fish passes.

claudio.comoglio@polito.it

Luca Ganis’

Born 1981. Degree in environmental engineering at Turin Polytechnic in the field of innovative applications of environmental management systems at territorial level (study of streams and watercourses in natural protected areas). Technician at Mont Avic Natural Park and expert in GIS mapping.

info@montavic.it

\section{Alessandro Nota ${ }^{2}$}

Born 1981. Degree in environmental engineering. $\mathrm{PhD}$ student at Turin Polytechnic in the field of innovative applications of environmental management systems at territorial level (natural protected areas, local authorities, etc.).

alessandro.nota@polito.it

${ }^{1}$ Mont Avic Natural Park, Loc. Fabbrica 164, 11020 Champdepraz AO, Italy.

www.montavic.it

2 Turin Polytechnic, Department of Territorial Engineering, Environment and Geotechnology, Corso Duca degli Abruzzi, 24, 10129 Turin, Italy

http://www.polito.it/ricerca/dipartimenti/ditag/index.php?lang=en 